ISSN 1112-9867

http://www.jfas.info

\title{
OPTIMIZATION OF ENZYMATIC HYDROLYSIS OF SKIPJACK TUNA BY-PRODUCT USING PROTAMEX®: A RESPONSE SURFACE APPROACH
}

\author{
Herpandi ${ }^{1}$, A. Rosma ${ }^{2}$, W. A. W. Nadiah ${ }^{2}$, N. A. Febrianto ${ }^{3}$ and N. Huda ${ }^{4, *}$ \\ ${ }^{1}$ Fisheries Product Technology Programme, Sriwijaya University, 30662 South Sumatra, \\ Indonesia \\ ${ }^{2}$ Bioprocess Technology Programme, Universiti Sains Malaysia, 11800 Penang, Malaysia \\ ${ }^{3}$ Indonesian Coffee and Cocoa Research Institute, 68175 East Java, Indonesia \\ ${ }^{4}$ School of Food Industry, Universiti Sultan Zainal Abidin, 22200 Terengganu, Malaysia
}

Published online: 08 August 2017

\begin{abstract}
The goal of this study was to optimize enzymatic hydrolysis of the dark flesh of skipjack tuna (Katsuwonus pelamis). Protamex ${ }^{\circledR}$ was used as the hydrolytic enzyme at various concentrations $(1 \%, 1.5 \%, 2 \%, 2.5 \%$ and $3 \% \mathrm{w} / \mathrm{w})$ at $\mathrm{pHs}$ from 6.5 to 8.5 , temperatures from 40 to $60{ }^{\circ} \mathrm{C}$ and times of 2 to $6 \mathrm{~h}$. The experiment was performed following a five-level second-order central composite design with six replications at the center points. The high coefficients of determination for degree of hydrolysis $(\mathrm{R} 2=0.9674)$ and free tryptophan content $(\mathrm{R} 2=0.9426)$ indicate the suitability of the design for predicting the responses. The optimum hydrolytic conditions predicted by the response surface methodology were $3 \%$ Protamex ${ }^{\circledR}$ at $\mathrm{pH} 6.57$ and $58^{\circ} \mathrm{C}$ for $4 \mathrm{~h}$. These conditions resulted in an experimental degree of hydrolysis of $18.48 \%$ and free tryptophan content of $72.10 \mathrm{mg} \mathrm{kg}-1$.
\end{abstract}

Keywords: Skipjack tuna; protein hydrolysate; response surface analysis; free tryptophan.

Author Correspondence, e-mail: nhuda@unisza.edu.my

doi: http://dx.doi.org/10.4314/jfas.v9i2s.55 


\section{INTRODUCTION}

Skipjack tuna (Katsuwonus pelamis) is one of the most economically important products of the tuna fishing industry. The global production of tuna has reached 4.5 million tons per year, and skipjack tuna accounts for $59.1 \%$ of total production [1]. The canned fish processing industry generates solid wastes that are composed of muscle, viscera, gills, dark flesh/dark muscle, head, bone, skin and this waste can reach up to $70 \%$ of the original raw material [2]. In [3] estimated the wastes of the tuna canning industry to be 450,000 tons annually. They also concluded that methods to add value to tuna processing by-products must be developed.

Dark muscle is a protein-rich part of the tuna. It is considered to be a by-product in the tuna canning industry because of its undesirable characteristics including unpleasant flavor, dark color and susceptibility to oxidation. Dark muscle is commonly used to produce low-market value products such as fish meal and fertilizer. An alternative use of this by-product is to convert it into fish protein hydrolysate (FPH), which is widely used in food systems. FPH has been made from fish by-products as well as underutilized fish species through the process of hydrolysis [4]. In [5] conducted studies of the enzymatic production of hydrolysate from tuna dark muscle, and in [6] highlighted the potential use of tuna dark muscle FPH in the pharmaceutical industry due to its antiproliferative and antioxidative effects. However, optimization of the enzymatic hydrolysis process for this fish by-product, especially that using Protamex ${ }^{\circledR}$, has not been reported previously.

FPH obtained from controlled enzymatic hydrolysis is among the best protein hydrolysates in terms of nutritional properties, balanced amino acid composition and high digestibility [4]. However, it is not used for human consumption because of its bitter flavor and fishy odor. Bitterness is a major problem affecting the sensory acceptability of protein hydrolysates. One of the amino acids contributing to the bitter taste is tryptophan [7-8]. To address this issue, we conducted tuna dark flesh hydrolysis using Protamex ${ }^{\circledR}$ and the response surface methodology to identify the optimal parameters for generating high hydrolysis activity and low free tryptophan production. We anticipate that the results may lead to the development of FPH from tuna dark muscle with acceptable (i.e., low) bitterness. 


\section{RESULTS AND DISCUSSION}

\subsection{Model Fitting}

Each of the response variables (Y) for DH and FT was fitted by a second-order polynomial response. The sequential model of sum of squares analyses indicated that adding up the quadratic terms significantly improved the model $(\mathrm{p}<0.0001$ and 0.0015 for DH and FT respectively) (Table 1). Therefore, the quadratic model is the most appropriate for modeling the $\mathrm{DH}$ and FT response. The corresponding coefficients of determination $\left(\mathrm{R}^{2}\right)$, adj- $\mathrm{R}^{2}$ and coefficients of variations (CV) can also indicate the adequacy of the model [9]. The high determination coefficients for the DH $\left(\mathrm{R}^{2}=0.9674\right)$ and FT $\left(\mathrm{R}^{2}=0.9426\right)$ response (Table 2$)$ indicate the suitability of the second-order polynomial for predicting the responses. These values are in agreement with [10] who reported that the $\mathrm{R}^{2}$ should not be $<80 \%$.

Table 1. Sequential model sum of squares of degree of hydrolysis and free tryptophan content response

\begin{tabular}{cccccc}
\hline $\begin{array}{c}\text { Source of } \\
\text { Variation }\end{array}$ & DF & \multicolumn{2}{c}{ DH (\%) } & \multicolumn{2}{c}{ FT (mg kg $\left.\mathbf{~ k g}^{\mathbf{- 1}}\right)$} \\
Mean & 1 & 8088.16 & & 254200 & \\
Linear & 4 & 11.06 & $<0.0001$ & 1335.76 & 0.0065 \\
Interaction & 6 & 0.61 & 0.6915 & 1178.79 & 0.0014 \\
Quadratic & 4 & 2.49 & $<0.0001$ & 460.42 & 0.0005 \\
Cubic & 8 & 0.26 & 0.5010 & 77.46 & 0.7190 \\
Residual & 7 & 0.22 & & 103.76 & \\
Total & 30 & 8102.80 & & 257400 & \\
\hline
\end{tabular}

DH: Degree of hydrolysis

FT: Free tryptophan content 
Table 2. Condensed ANOVA results for the response surface quadratic model of dependent variables

\begin{tabular}{|c|c|c|c|c|c|}
\hline \multirow{2}{*}{$\begin{array}{l}\text { Source of } \\
\text { Variations }\end{array}$} & \multirow{2}{*}{ DF } & \multicolumn{2}{|c|}{ DH (\%) } & \multicolumn{2}{|c|}{ FT $\left(\mathrm{mg} \mathrm{kg}^{-1}\right)$} \\
\hline & & Sum of Squares & P Value & Sum of Squares & P Value \\
\hline model & 14 & 14.16 & $<0.0001$ & 2974.97 & $<0.0001$ \\
\hline $\mathrm{X}_{1}$ & 1 & 1.10 & $<0.0001$ & 465.17 & $<0.0001$ \\
\hline $\mathrm{X}_{2}$ & 1 & 6.54 & $<0.0001$ & 282.15 & 0.0002 \\
\hline $\mathrm{X}_{3}$ & 1 & 2.79 & $<0.0001$ & 423.70 & $<0.0001$ \\
\hline $\mathrm{X}_{4}$ & 1 & 0.62 & 0.0005 & 164.75 & 0.0022 \\
\hline $\mathrm{X}_{1} \mathrm{X}_{2}$ & 1 & 0.0005063 & 0.9013 & 128.26 & 0.0053 \\
\hline $\mathrm{X}_{1} \mathrm{X}_{3}$ & 1 & 0.077 & 0.1406 & 148.05 & 0.0032 \\
\hline $\mathrm{X}_{1} \mathrm{X}_{4}$ & 1 & 0.47 & 0.0016 & 406.32 & $<0.0001$ \\
\hline $\mathrm{X}_{2} \mathrm{X}_{3}$ & 1 & 0.005256 & 0.6902 & 24.40 & 0.1757 \\
\hline $\mathrm{X}_{2} \mathrm{X}_{4}$ & 1 & 0.004556 & 0.7104 & 80.01 & 0.0212 \\
\hline $\mathrm{X}_{3} \mathrm{X}_{4}$ & 1 & 0.047 & 0.2416 & 391.74 & $<0.0001$ \\
\hline $\mathrm{X}_{1}^{2}$ & 1 & 0.26 & 0.0114 & 77.33 & 0.0231 \\
\hline $\mathrm{X}_{2}^{2}$ & 1 & 1.12 & $<0.0001$ & 315.27 & 0.0001 \\
\hline $\mathrm{X}_{3}^{2}$ & 1 & 0.70 & 0.0003 & 3.89 & 0.5788 \\
\hline $\mathrm{X}_{4}^{2}$ & 1 & 0.20 & 0.0255 & 171.30 & 0.0019 \\
\hline Residual & 15 & 0.48 & & 181.22 & \\
\hline Lack of fit & 10 & 0.41 & 0.1114 & 153.36 & 0.1376 \\
\hline Pure error & 5 & 0.066 & & 27.86 & \\
\hline Total & 29 & 14.63 & & 3156.19 & \\
\hline $\mathrm{R}^{2}$ & & 0.9674 & & 0.942 & \\
\hline Adj-R ${ }^{2}$ & & 0.9369 & & 0.889 & \\
\hline CV (\%) & & 1.09 & & 3.78 & \\
\hline
\end{tabular}

Variables $\mathrm{X}_{1}$ : Time, $\mathrm{X}_{2}$ : Temperature, $\mathrm{X}_{3}$ : Protamex ${ }^{\circledR}$ concentration, $\mathrm{X}_{4}$ : $\mathrm{pH}$

The high value of $\mathrm{R}^{2}$ must be followed by close value of adj- $\mathrm{R}^{2}$ to make sure that the 
non-significant terms have not been included in the model [9]. In our study, the adj- $\mathrm{R}^{2}$ values were quite high (0.9369 and 0.889 for DH and FT respectively) and the coefficients of variations were low (1.09 and 3.78 for DH and FT respectively). The latter show enough precision and reliability to assure that the quadratic model can adequately model the responses. Moreover, good agreement between the actual experimental results and the predicted values generated by the polynomial regression model (Fig. 1) suggests that the quadratic model is able to identify the optimal conditions for hydrolysis of tuna dark flesh to produce FPH.
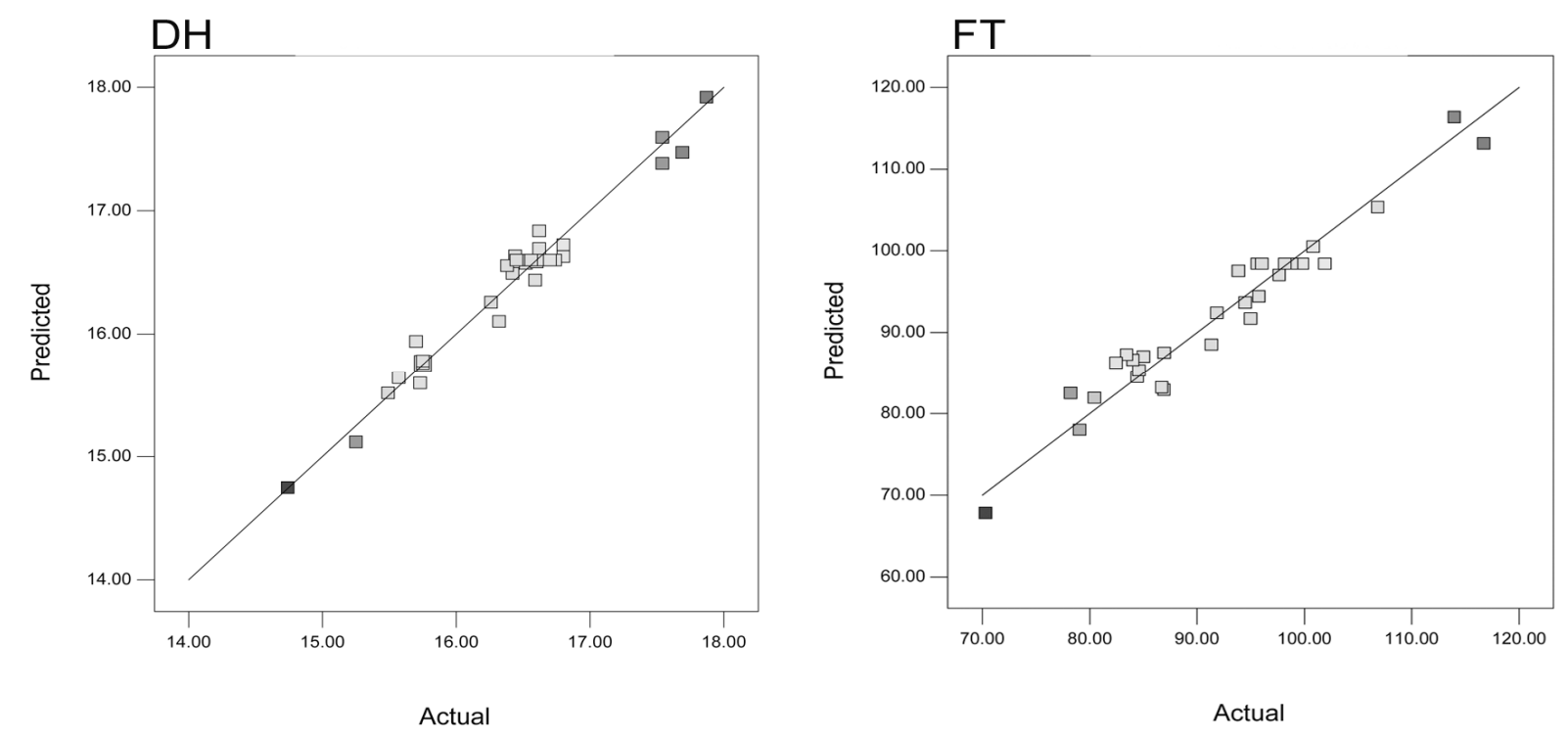

Fig.1. Comparison between predicted and actual values of degree of hydrolysis and free tryptophan content

\subsection{Degree of Hydrolysis}

The DH values in the experiments varied from $14.74 \%$ to $17.87 \%$. This result is in agreement with results reported by [11]. They showed $16-18 \% \mathrm{DH}$ to be the optimum activity of endogenous enzymes, which is within the acceptable range (10-20\%) quoted by [12] for Protamex ${ }^{\circledR}$. A significant $p$ value $(p<0.0001)$ for linear effects of time, temperature, Protamex ${ }^{\circledR}$ concentration and $\mathrm{pH}$ shows that these variables significantly affected the $\mathrm{DH}$. Increasing the temperature of hydrolysis of dark flesh induced an increase in the DH, although when a certain temperature was reached, the $\mathrm{DH}$ value began to decline. The time variables showed a similar trend, although the fluctuation was not pronounced (Fig. 2). The DH value rose with increased concentration of Protamex ${ }^{\circledR}$, whereas the effects of the $\mathrm{pH}$ conditions were variable. The interaction of time and $\mathrm{pH}(\mathrm{p}=0.0016)$ and the quadratic effect of temperature $(\mathrm{p}$ 
$<0.0001)$ and Protamex ${ }^{\circledR}$ concentration $(p=0.0003)$ were significant, but the quadratic effect of time $(\mathrm{p}=0.0114)$ and $\mathrm{pH}(\mathrm{p}=0.0255)$ were not.

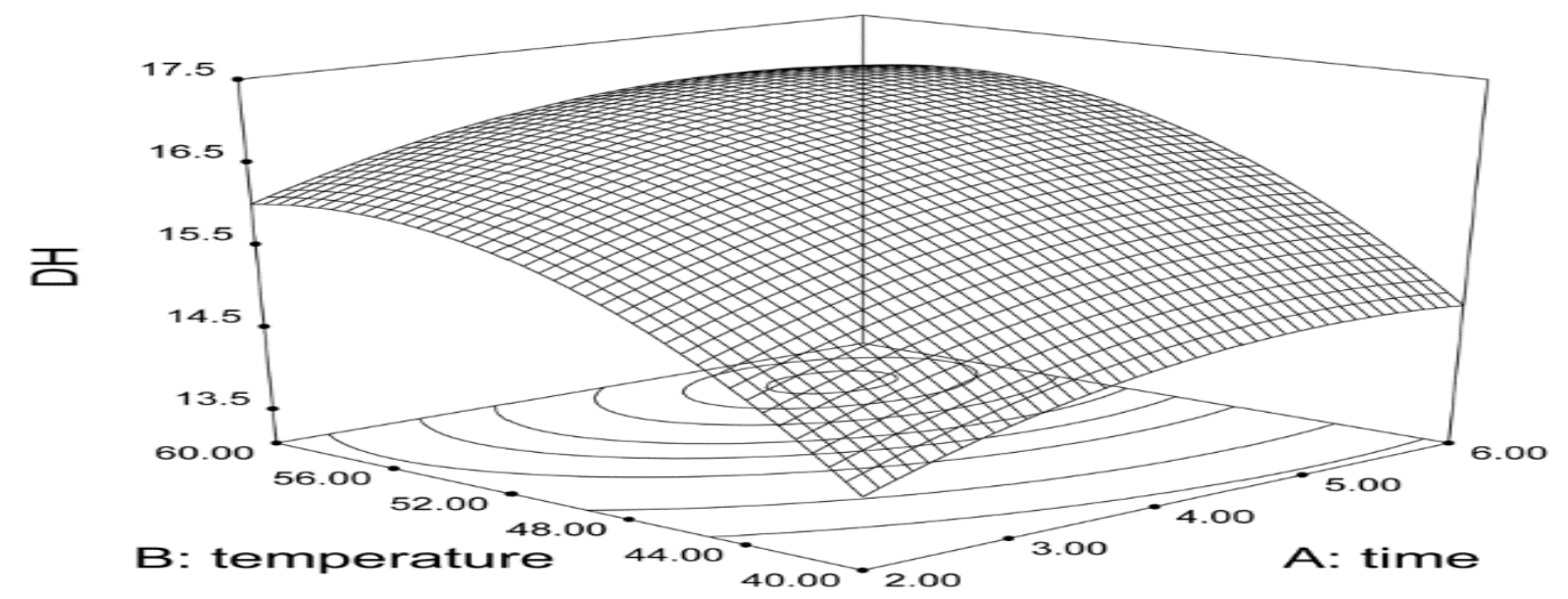

Fig.2. Response surface of degree of hydrolysis (DH) for the effect of time (h) and temperature $\left({ }^{\circ} \mathrm{C}\right)$ at constant $\mathrm{pH}(7.5)$ and Protamex ${ }^{\circledR}$ concentration $(2 \%)$

According to the Protamex ${ }^{\circledR}$ application sheet [12], the optimum temperature of hydrolysis is $50{ }^{\circ} \mathrm{C}$ at $\mathrm{pH} 7-8$. However, the optimization results obtained using the response surface methodology for the single response of DH showed that maximum DH was obtained at 56.85 ${ }^{\circ} \mathrm{C}$ and pH 7.42 (Table 3). The differences in raw material used could affect the enzymatic hydrolysis. In [13] found that the optimum conditions for hydrolysate production from Alaska pollock (Theragra chalcogramma) frame using Protamex ${ }^{\circledR}$ were $50^{\circ} \mathrm{C}$ and $\mathrm{pH} 7.2$, which resulted $\pm 12 \% \mathrm{DH}$. In [14] reported $50{ }^{\circ} \mathrm{C}$ and $\mathrm{pH} 8$ to be the optimum conditions for hydrolysis of cuttlefish (Sepia officinalis) and sardine (Sardina pilchardus) viscera. Similarly, in [15] showed $50{ }^{\circ} \mathrm{C}$ and $\mathrm{pH} 6.5$ to be the optimum conditions for hydrolysate production from loach (Misgurnus anguillicaudatus) using Protamex ${ }^{\circledR}$. When alcalase enzymes were used, in [16] reported the optimum conditions for hydrolysis of Pacific whiting (Merluccius productus) to be $60{ }^{\circ} \mathrm{C}$ and $\mathrm{pH} 9.5$ whereas in [17] found $50{ }^{\circ} \mathrm{C}$ and $\mathrm{pH} 8.5$ to be optimal for hydrolysis of catla (Catla catla) using the same enzyme. 
Table 3. Regression equations for the response functions in the actual level of variables

$$
\begin{aligned}
\hline \mathrm{Y}_{1}= & -20.5224-1.79979 \mathrm{X}_{1}+0.95296 \mathrm{X}_{2}-1.15208 \mathrm{X}_{3}+4.14375 \mathrm{X}_{4}-0.001125 \mathrm{X}_{1} \mathrm{X}_{2}+ \\
& 0.13875 \mathrm{X}_{1} \mathrm{X}_{3}+0.34375 \mathrm{X}_{1} \mathrm{X}_{4}+0.00725 \mathrm{X}_{2} \mathrm{X}_{3}-0.00675 \mathrm{X}_{2} \mathrm{X}_{4}-0.2175 \mathrm{X}_{3} \mathrm{X}_{4}- \\
& 0.098229 \mathrm{X}_{1}^{2}-0.008079 \mathrm{X}_{2}^{2}+0.63708 \mathrm{X}_{3}^{2}-0.33792 \mathrm{X}_{4}^{2} \\
\mathrm{Y}_{2}= & -400.09448-98.23562 \mathrm{X}_{1}+16.33125 \mathrm{X}_{2}-183.05042 \mathrm{X}_{3}+120.00875 \mathrm{X}_{4}+ \\
& 0.56625 \mathrm{X}_{1} \mathrm{X}_{2}+6.08375 \mathrm{X}_{1} \mathrm{X}_{3}+10.07875 \mathrm{X}_{1} \mathrm{X}_{4}+0.494 \mathrm{X}_{2} \mathrm{X}_{3}-0.8945 \mathrm{X}_{2} \mathrm{X}_{4}+ \\
& 19.7925 \mathrm{X}_{3} \mathrm{X}_{4}-1.67906 \mathrm{X}_{1}^{2}-0.13561 \mathrm{X}_{2}^{2}-1.50625 \mathrm{X}_{3}^{2}-9.99625 \mathrm{X}_{4}^{2}
\end{aligned}
$$

Variables $\mathrm{X}_{1}$ : Time, X2: Temperature, $\mathrm{X} 3$ : Protamex ${ }^{\circledR}$ concentration, $\mathrm{X} 4$ : $\mathrm{pH}$ response: $\mathrm{Y}_{1}$ :

Degree of hydrolysis, $\mathrm{Y}_{2}$ : Free tryptophan content

The significant quadratic effect of time is shown by the increase in the $\mathrm{DH}$ value prior to the stationary and slight decrease inclination. In [14] noticed the same pattern in the hydrolysis of cuttlefish and sardine viscera when Protamex ${ }^{\circledR}$ was used, stagnation began to occur at the third hour. In [2] also described stagnation of the enzymatic hydrolysis of tuna stomach reacted with Alcalase after incubation for $5-6 \mathrm{~h}$ at $50{ }^{\circ} \mathrm{C}$ and $\mathrm{pH}$ 8.0. They attributed the stagnation to limitation of either substrate or the enzyme. In [18] ascribed these phenomena to a decrease of available peptide bonds that led to a decrease in enzyme activity and product inhibition, which in turn contributed to the downward tendency of the hydrolysis curve.

The interaction of time and $\mathrm{pH}$ also significantly affected the hydrolysis process. Generally, the DH value increased with increasing hydrolysis time at high pH (Fig. 4). In [19] reported a similar trend for hydrolysis of Persian sturgeon (Acipenser persicus) visceral protein. In their study, the hydrolysis curve tended to rise with increasing time of hydrolysis to reach a maximum $\mathrm{DH}$ at $\sim 3.5 \mathrm{~h}$ at $\mathrm{pH}$ 8.5. In threadfin bream hydrolysate production, in [20] reported that the DH curve continued to rise for the first $4 \mathrm{~h}$ of the hydrolysis process. When Flavourzyme ${ }^{\mathrm{TM}}$ and Kojizyme ${ }^{\mathrm{TM}}$ were used to hydrolyze fish soluble concentrate, the DH curve was still increasing past $5 \mathrm{~h}$ of reaction time [21]. In contrast, research by [12] reported that the maximum value of DH was reached within a relatively short time (15-30 min), followed by a stationary phase and then a decrease. This result agrees with our finding of a high DH value during the first hour of hydrolysis at $\mathrm{pH} 6.5$ followed by a continuous decrease after $3 \mathrm{~h}$ (Fig. 3). 


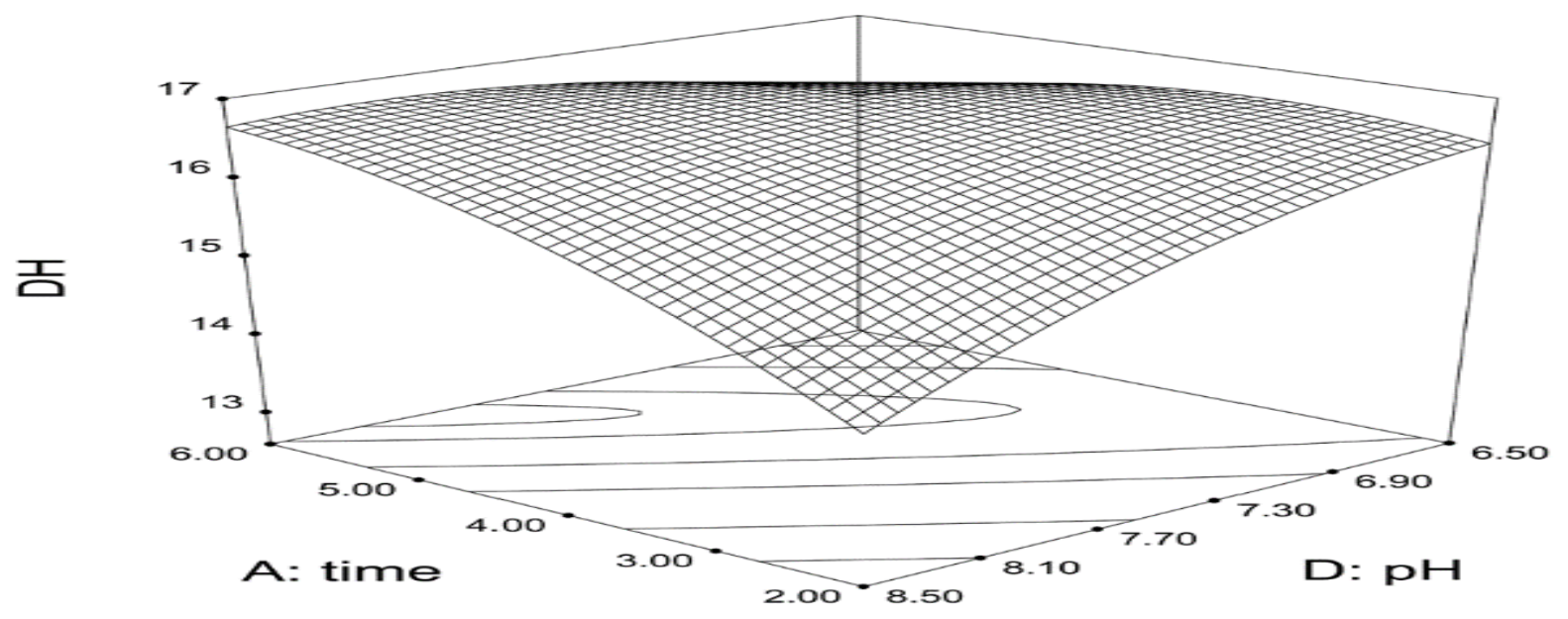

Fig.3. Response surface of degree of hydrolysis (DH) for the effect of time (h) and pH at constant Protamex ${ }^{\circledR}$ concentration $(2 \%)$ and temperature $\left(50{ }^{\circ} \mathrm{C}\right)$

\subsection{Free Tryptophan Content}

In our study, FT content was affected by all four variables and their interactions, except for the interaction of temperature and Protamex ${ }^{\circledR}$ concentration and the quadratic value of time and Protamex ${ }^{\circledR}$ concentration (Table 1). The time variable had the most significant effect. The interaction of time with the other three variables showed similar trends. Longer hydrolysis time at high $\mathrm{pH}$, high Protamex ${ }^{\circledR}$ concentration or high temperature produced higher FT content and hydrolysis for longer durations at low $\mathrm{pH}$ or low temperature resulted in lower FT content. In addition to the time variable, the Protamex ${ }^{\circledR}$ concentration had a significant linear effect on the hydrolysis process. Generally, increased enzyme concentration used in conjunction with any of the other factors produced hydrolysate with a higher FT content. The quadratic values of temperature and $\mathrm{pH}$ also had significant effects on the process. However, at longer times and higher Protamex ${ }^{\circledR}$ concentration, FT production was significantly increased as the $\mathrm{pH}$ of the reaction increased.

Because bitterness is an undesirable component in a food product, bitterness (represented here by the FT content) has to be as low as possible. The FT values in our experiment varied from 70.33 to $116.71 \mathrm{ppm}(\mathrm{w} / \mathrm{w})$ hydrolysate (Table 6$)$, thus they were under the tryptophan threshold of bitterness in food products $\left(1021.15 \mathrm{ppm}\right.$ in water, eqv $\left.5 \mathrm{mmol} \mathrm{L}^{-1}\right)$ [22]. We found that DH and FT were positively correlated, which means that the FT content increased as the DH increased. This result agreed with that of [21] who noted that free tryptophan content 
continuously increased during enzymatic hydrolysis of fish soluble protein. However, in our optimization study using the response surface methodology, the model predicted the DH and FT responses (maximize DH and minimize FT) to be $18.55 \% \mathrm{DH}$ and an acceptable value of FT of $70.32 \mathrm{mg} \mathrm{kg}^{-1}$. In the actual experiment (validation), the values were $18.48 \% \mathrm{DH}$ and 72.10 $\mathrm{mg} \mathrm{kg}^{-1}$ FT (Table 4).

Table 4. Optimal conditions for enzymatic hydrolysis of skipjack tuna by-product

\begin{tabular}{|c|c|c|c|c|c|c|c|}
\hline \multirow{2}{*}{$\begin{array}{l}\text { Time } \\
\left(\mathbf{X}_{1}\right)\end{array}$} & \multirow{2}{*}{$\begin{array}{c}\text { Temperature } \\
\left(\mathrm{X}_{2}\right)\end{array}$} & \multirow{2}{*}{$\begin{array}{c}\text { Protamex® } \\
\text { Concentration } \\
\left(\mathbf{X}_{3}\right)\end{array}$} & \multirow{2}{*}{$\begin{array}{c}\text { pH } \\
\left(\mathbf{X}_{4}\right)\end{array}$} & \multicolumn{2}{|c|}{ Predicted } & \multicolumn{2}{|c|}{ Experimental } \\
\hline & & & & DH (\%) & $\begin{array}{c}\text { FT } \\
\left(\mathrm{mg} \mathrm{kg}^{-1}\right)\end{array}$ & $\begin{array}{l}\text { DH } \\
(\%)\end{array}$ & $\begin{array}{c}\text { FT } \\
\left(\mathrm{mg} \mathrm{kg}^{-1}\right)\end{array}$ \\
\hline 4.0 & 58.0 & 3.0 & 6.57 & 18.55 & 70.32 & 18.48 & 72.10 \\
\hline
\end{tabular}

\section{EXPERIMENTAL}

\subsection{Raw Materials and Chemicals}

Skipjack tuna by-product (dark flesh) was obtained from PT. Medan Tropical Canning and Frozen Industries (Medan, Indonesia), transported to the laboratory in a frozen state and kept at $-20{ }^{\circ} \mathrm{C}$ until use. Protamex ${ }^{\circledR}$ was obtained from Novo Nordisk (Bagsværd, Denmark) and stored at $4{ }^{\circ} \mathrm{C}$ until use. Tryptophan standard (5-Fluoro-L-tryptophan $\geq 98.0 \%$ (HPLC)) was purchased from Sigma-Aldrich (St. Louis, MO, USA). All chemical reagents used for the experiments were analytical grade.

\subsection{Production of Protein Hydrolysate}

Thawed skipjack tuna dark flesh was minced in a blixer (Robot Coupe, Vincennes Cedex, France) and then heated for endogenous enzymes inactivation and fat removal at $85{ }^{\circ} \mathrm{C}$ for 20 min in a wise-water bath (Daihan Scientific, Seoul, Korea) [23]. The treated material was then cooled and centrifuged at $3500 \mathrm{rpm}$ for $20 \mathrm{~min}$ at $4{ }^{\circ} \mathrm{C}$ (Union $5 \mathrm{KR}$ centrifuge, Hanil Science Industry, Gyeyang-gu Incheon, Korea) to separate the oil. The separated oil was removed and the protein-rich solid was used for the experiments. The protein-rich solid (sample) was mixed with sodium phosphate buffer 1:2(w/v) and homogenized for 2 min at ambient temperature. The $\mathrm{pH}$ of the mixture was adjusted to $6.5,7.0,7.5,8.0$ and 8.5 by adding $2 \mathrm{~N} \mathrm{NaOH}$. Different concentrations of Protamex ${ }^{\circledR}(1 \%, 1.5 \%, 2 \%, 2.5 \%$ and $3 \% \mathrm{w} / \mathrm{w})$ were added to the 
protein-rich solid sample. All reactions were performed in $250 \mathrm{ml}$ conical flasks in a shaking incubator (LM-570R Orbital Shaker Incubator, Chemist Scientific Corp., Taipei Hsien, Taiwan) with constant agitation $(200 \mathrm{rpm})$ at 40, 45, 50, 55 and $60{ }^{\circ} \mathrm{C}$ for 2, 3, 4, 5 and $6 \mathrm{~h}$. After each treatment, the reaction was terminated by heating the solution in a water bath at 85 ${ }^{\circ} \mathrm{C}$ for $10 \mathrm{~min}$ (JP Selecta SA, Barcelona, Spain) to assure inactivation of the enzyme. The hydrolysate then was cooled in ice to room temperature and centrifuged at $10000 \mathrm{rpm}$ at $4{ }^{\circ} \mathrm{C}$ for $20 \mathrm{~min}$ in a Kubota 6500 centrifuge (Tokyo, Japan) to collect the supernatant.

\subsection{Degree of Hydrolysis}

Degree of hydrolysis (DH) was estimated following [24]. To the supernatant, one volume of $20 \%$ trichloroacetic acid (TCA) was added, followed by centrifugation at $10000 \mathrm{rpm}$ at $4{ }^{\circ} \mathrm{C}$ for $10 \mathrm{~min}$ to collect the $10 \%$ TCA-soluble materials. Total nitrogen in the $10 \%$ TCA soluble material and the substrate was estimated by the Kjeldahl method using a Kjeltec protein analyzer (FOSS analytical AB, Hoeganaes, Sweden). The DH was calculated as:

$$
10 \% \mathrm{TCA}+\text { soluble } \mathrm{N}_{2} \text { in the sample }
$$

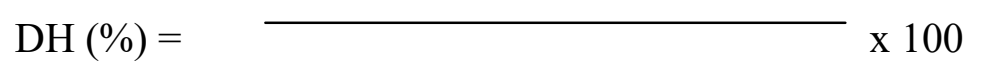

Total $\mathrm{N}_{2}$ in the sample

\subsection{Free Tryptophan Content}

Free tryptophan (FT) content was determined following [25]. A $250 \mathrm{mg}$ aliquot of the freeze dried sample was placed in a volumetric flask and diluted to $25 \mathrm{~mL}$ with acidic water (ultra-pure water adjusted to $\mathrm{pH} 6.3$ with $0.1 \mathrm{M} \mathrm{HCl}$ ) to obtain a concentration of $10 \mathrm{mg} \mathrm{mL}^{-1}$. Afterwards, the samples were sonicated (Elma Hans Schmidbauer GmbH and Co. KG, Singen, Germany) for 2 min to allow complete dissolution to occur. The solution was then analyzed using a HPLC system (Waters Corporation, Milford, MA, USA) equipped with a Waters Alliance 2690 Separation Module, a Waters fluorescence detector and a Waters Millennium 32 workstation version 3.2. The separation was performed with a Hypersil ODS C18 column $(250 \times 4.6 \mathrm{~mm}, 5 \mu \mathrm{m})($ Thermo Scientific, Waltham, MA, USA) fitted with a Hypersil ODS guard column. The mobile phase consisted of the mixture of methanol: $40 \mathrm{mM}$ sodium acetate buffer (adjusted to $\mathrm{pH} 4.5$ with acetic acid; 20:80, v/v) filtered through a $0.22 \mathrm{~mm}$ membrane and degassed; a flow rate of $1.00 \mathrm{~mL} \mathrm{~min}^{-1}$ and column temperature of $26{ }^{\circ} \mathrm{C}$ was used. The 
fluorescence was recorded at the optimal wavelengths for tryptophan $\left(\lambda_{\mathrm{ex}}=280 \mathrm{~nm}\right.$ and $\lambda_{\mathrm{em}}=$ $348 \mathrm{~nm}$ ) for another $15 \mathrm{~min}$.

\subsection{Statistical Analysis}

The experiment was performed using the central composite design with six replications of the center points and five levels of each of four variables. The five levels were coded as $-2,-1,0,+1$ and +2 using Design Expert ${ }^{\circledR}$ version 8.0.0 (Stat-Ease, Inc. Minneapolis, MN, USA). The independent variables were $\mathrm{X}_{1}$ (time, $\left.\mathrm{h}\right), \mathrm{X}_{2}$ (temperature, ${ }^{\circ} \mathrm{C}$ ), $\mathrm{X}_{3}$ (Protamex ${ }^{\circledR}$ concentration, $\%$ ) and $\mathrm{X}_{4}(\mathrm{pH})$. Table 5 shows the experimental design for the actual (X) and coded (x) levels of variables, whereas Table 2 shows the results of the analysis.

Table 5. The level of selected factors in actual and coded form

\begin{tabular}{ccc}
\hline Factor & Actual Conditions & Coded Level \\
\hline Time $(\mathrm{h})$ & $2,3,4,5$ and 6 & $-2,-1,0,+1,+2$ \\
Temperature $\left({ }^{\circ} \mathrm{C}\right)$ & $40,45,50,55$ and 60 & $-2,-1,0,+1,+2$ \\
Protamex ${ }^{\circledR}$ concentration $(\%)$ & $1.0,1.5,2.0,2.5$ and 3.0 & $-2,-1,0,+1,+2$ \\
$\mathrm{pH}$ & $6.5,7.0,7.5,8.0$ and 8.5 & $-2,-1,0,+1,+2$ \\
\hline
\end{tabular}

The response function Y for DH and FT was approximated by a second-degree polynomial using Equation (1):

$\mathrm{Y}=\mathrm{b}_{0}+\mathrm{b}_{1} \mathrm{X}_{1}+\mathrm{b}_{2} \mathrm{X}_{2}+\mathrm{b}_{3} \mathrm{X}_{3}+\mathrm{b}_{4} \mathrm{X}_{4}+\mathrm{b}_{12} \mathrm{X}_{1} \mathrm{X}_{2}+\mathrm{b}_{13} \mathrm{X}_{1} \mathrm{X}_{3}+\mathrm{b}_{14} \mathrm{X}_{1} \mathrm{X}_{4}+\mathrm{b}_{23} \mathrm{X}_{2} \mathrm{X}_{3}+\mathrm{b}_{24} \mathrm{X}_{2} \mathrm{X}_{4}+$ $\mathrm{b}_{34} \mathrm{X}_{3} \mathrm{X}_{4}+{ }_{\mathrm{b} 11 \mathrm{X} 21}+\mathrm{b}_{22} \mathrm{X}_{2}{ }_{2}+\mathrm{b}_{33} \mathrm{X}^{2}{ }_{3}+\mathrm{b}_{44} \mathrm{X}_{4}{ }_{4}+\varepsilon$

The linear, interaction and quadratic effects are represented along with the coefficient (b0) by b1, b2, b3 and b4 (linear effects); b12, b13, b14, b23, b24 and b34 (interaction effects); and b11, b22, b33 and b44 (quadratic effects). The adequacy of the model was checked by accounting of fit summary generated by the Design Expert software (Table 6). The optimum conditions were determined using the Myers and Montgomery desirability method contained in the software, the chosen desired goal were the independent variables were kept within in range whereas the response for DH was maximized and that for FT was minimized. 
Table 6. Central composite design for effect of hydrolysis variables on degree of hydrolysis and free tryptophan content of tuna dark muscle

\begin{tabular}{|c|c|c|c|c|c|c|}
\hline \multirow[t]{2}{*}{ Run } & \multirow{2}{*}{$\begin{array}{l}\text { Time (h) } \\
\text { Coded } x_{1}\end{array}$} & \multirow{2}{*}{$\begin{array}{c}\text { Temperature } \\
\left({ }^{\circ} \mathrm{C}\right) \\
\text { Coded } x_{2}\end{array}$} & \multirow{2}{*}{$\begin{array}{c}\text { Protamex }{ }^{\circledR} \\
\text { Conc. }(\%) \\
\text { Coded } x_{3}\end{array}$} & \multirow{2}{*}{$\begin{array}{c}\text { pH } \\
\text { Coded } x_{4}\end{array}$} & \multicolumn{2}{|c|}{ Result } \\
\hline & & & & & DH* $(\%)$ & $\begin{array}{c}\mathrm{FT}^{* *} \\
\left(\mathrm{mg} \mathrm{kg}^{-1}\right)\end{array}$ \\
\hline 1 & -1 & -1 & -1 & -1 & 15.57 & 93.88 \\
\hline 2 & 1 & -1 & -1 & -1 & 15.73 & 84.44 \\
\hline 3 & -1 & 1 & -1 & -1 & 16.62 & 85.04 \\
\hline 4 & 1 & 1 & -1 & -1 & 16.80 & 84.61 \\
\hline 5 & -1 & -1 & -1 & 1 & 15.25 & 83.47 \\
\hline 6 & 1 & -1 & -1 & 1 & 15.75 & 95.79 \\
\hline 7 & -1 & 1 & -1 & 1 & 16.32 & 70.33 \\
\hline 8 & 1 & 1 & -1 & 1 & 16.80 & 82.48 \\
\hline 9 & -1 & -1 & 1 & -1 & 16.26 & 86.95 \\
\hline 10 & 1 & -1 & 1 & -1 & 17.54 & 84.05 \\
\hline 11 & -1 & 1 & 1 & -1 & 17.54 & 80.47 \\
\hline 12 & 1 & 1 & 1 & -1 & 15.25 & 91.86 \\
\hline 13 & -1 & -1 & 1 & 1 & 15.49 & 97.67 \\
\hline 14 & 1 & -1 & 1 & 1 & 16.59 & 113.97 \\
\hline 15 & -1 & 1 & 1 & 1 & 16.52 & 78.25 \\
\hline 16 & 1 & 1 & 1 & 1 & 17.69 & 116.71 \\
\hline 17 & -2 & 0 & 0 & 0 & 15.75 & 86.94 \\
\hline 18 & 2 & 0 & 0 & 0 & 16.44 & 100.84 \\
\hline 19 & 0 & -2 & 0 & 0 & 14.74 & 95.00 \\
\hline 20 & 0 & 2 & 0 & 0 & 16.38 & 79.09 \\
\hline 21 & 0 & 0 & 0 & -2 & 16.60 & 86.73 \\
\hline 22 & 0 & 0 & 0 & 2 & 15.70 & 94.49 \\
\hline 23 & 0 & 0 & -2 & 0 & 16.38 & 91.37 \\
\hline
\end{tabular}




\begin{tabular}{rrrrrrr}
\hline 24 & 0 & 0 & 2 & 0 & 17.87 & 106.84 \\
25 & 0 & 0 & 0 & 0 & 16.50 & 99.86 \\
26 & 0 & 0 & 0 & 0 & 16.65 & 95.64 \\
27 & 0 & 0 & 0 & 0 & 16.74 & 101.91 \\
28 & 0 & 0 & 0 & 0 & 16.56 & 98.84 \\
29 & 0 & 0 & 0 & 0 & 16.45 & 98.20 \\
30 & 0 & 0 & 0 & 0 & 16.70 & 96.05 \\
\hline
\end{tabular}

* DH: Degree of hydrolysis (mean of three triplicate measurements)

** FT: Free tryptophan content (mean of three triplicate measurements)

\section{CONCLUSION}

In this study, the production of FPH from skipjack tuna dark flesh using the Protamex ${ }^{\circledR}$ enzyme was successfully performed and optimized. The FT produced in all of the experiments was under the tryptophan threshold of bitterness in food products. The optimized conditions for both FT and $\mathrm{DH}$ were $58{ }^{\circ} \mathrm{C}, \mathrm{pH} 6.57,3 \%$ Protamex ${ }^{\circledR}$ for $4 \mathrm{~h}$ and these conditions resulted in experimental values of $18.48 \% \mathrm{DH}$ and FT content of $72.10 \mathrm{mg} \mathrm{kg}-1$. These values are acceptable for implementation in food industries. The response surface method proved to be effective for studying the optimization of the enzymatic hydrolysis process of skipjack tuna dark flesh using Protamex ${ }^{\circledR}$.

\section{ACKNOWLEDGEMENTS}

The authors acknowledge with gratitude the support given by Sriwijaya University, Universiti Sains Malaysia and Universiti Sultan Zainal Abidin. This project was funded through University grant 1001/PTEKIND/843003. 


\section{REFERENCES}

[1] Food and Agriculture Organization (FAO) of the United Nations. Fishery statistical collections: Global tuna catches by stock 1950-2010. Quebec: FAO, 2010

[2] Guerard F, Guimas L, Binet A. Production of tuna waste hydrolysates by a commercial neutral protease preparation. Journal of Molecular Catalysis B: Enzymatic, 2002, 19:489-498

[3] Sutanbawa Y, Aknes A, Tuna process waste an unexploited resource. Infofish International, $2006,3: 37-40$

[4] Kristinsson H G, Rasco B A. Biochemical and functional properties of Atlantic salmon (Salmo salar) muscle proteins hydrolyzed with various alkaline proteases. Journal of Agricultural and Food Chemistry, 2000, 48(3):657-666

[5] Hsu K C. Purification of antioxidative peptides prepared from enzymatic hydrolysates of tuna dark muscle by-product. Food Chemistry, 2010, 122(1):42-48

[6] Hsu K C, Li-Chan E C, Jao C L. Antiproliferative activity of peptides prepared from enzymatic hydrolysates of tuna dark muscle on human breast cancer cell line MCF-7. Food Chemistry, 2011, 126(2):617-622.

[7] Pedersen B. Removing bitterness from protein hydrolysates. Food Technology, 1994, 45:96-98

[8] Delwiche J F, Buletic Z, Breslin P A. Covariation in individuals' sensitivities to bitter compounds: Evidence supporting multiple receptor/transduction mechanisms. Attention, Perception, and Psychophysics, 2001, 63(5):761-776

[9] Koocheki A, Taherian A R, Razavi S M, Bostan A. Response surface methodology for optimization of extraction yield, viscosity, hue and emulsion stability of mucilage extracted from Lepidium perfoliatum seeds. Food Hydrocolloids, 2009, 23(8):2369-2379

[10] Little T. M., Hills F. J. Agricultural experimentation design and analysis. New York: John Wiley and Sons, 1978

[11] Pastoriza L, Sampedro G, Cabo M L, Herrera J J, Bernárdez M. Solubilisation of proteins from rayfish residues by endogenous and commercial enzymes. Journal of the Science of Food and Agriculture, 2004, 84(1):83-88

[12] Novozymes. Protamex ${ }^{\circledR}$ application sheet. Bagsværd: Novozymes, 2001 
[13] Hou H, Li B, Zhao X, Zhang Z, Li P. Optimization of enzymatic hydrolysis of Alaska pollock frame for preparing protein hydrolysates with low-bitterness. LWT-Food Science and Technology, 2011, 44(2):421-428

[14] Kechaou E S, Dumay J, Donnay-Moreno C, Jaouen P, Gouygou J P, Bergé J P, Amar R B. Enzymatic hydrolysis of cuttlefish (Sepia officinalis) and sardine (Sardina pilchardus) viscera using commercial proteases: Effects on lipid distribution and amino acid composition. Journal of Bioscience and Bioengineering, 2009, 107(2):158-164

[15] You L, Zhao M, Cui C, Zhao H, Yang B. Effect of degree of hydrolysis on the antioxidant activity of loach (Misgurnus anguillicaudatus) protein hydrolysates. Innovative Food Science and Emerging Technologies, 2009, 10(2):235-240

[16] Benjakul S, Morrissey M T. Protein hydrolysates from Pacific whiting solid wastes. Journal of Agricultural and Food Chemistry, 1997, 45(9):3423-3430

[17] Bhaskar N, Benila T, Radha C, Lalitha R G. Optimization of enzymatic hydrolysis of visceral waste proteins of Catla (Catla catla) for preparing protein hydrolysate using a commercial protease. Bioresource Technology, 2008, 99(2):335-343

[18] Moreno M M, Cuadrado V F. Enzymic hydrolysis of vegetable proteins: Mechanism and kinetics. Process Biochemistry, 1993, 28(7):481-490

[19] Ovissipour M, Abedian A, Motamedzadegan A, Rasco B, Safari R, Shahiri H. The effect of enzymatic hydrolysis time and temperature on the properties of protein hydrolysates from Persian sturgeon (Acipenser persicus) viscera. Food Chemistry, 2009, 115(1):238-242

[20] Normah I, Jamilah B, Saari N, Yaakob B. Optimization of hydrolysis conditions for the production of threadfin bream (Nemipterus japonicus) hydrolysate by Alcalase. Journal of Muscle Foods, 2005, 16(2):87-102

[21] Nilsang S, Lertsiri S, Suphantharika M, Assavanig A. Optimization of enzymatic hydrolysis of fish soluble concentrate by commercial proteases. Journal of food Engineering, 2005, 70(4):571-578

[22] Warmke R, Belitz H D. Influence of glutamic acid on the bitter taste of various compounds. Zeitschrift für Lebensmitteluntersuchung und-Forschung A, 1993, 197(2):132-133 
[23] Guerard F, Dufosse L, De La Broise D, Binet A. Enzymatic hydrolysis of proteins from yellowfin tuna (Thunnus albacares) wastes using Alcalase. Journal of Molecular Catalysis B: Enzymatic, 2001, 11(4):1051-1059

[24] Hoyle N T, Merrltt J O. Quality of fish protein hydrolysates from herring (Clupea harengus). Journal of food Science, 1994, 59(1):76-79

[25] Sanchez-Machado D I, Chavira-Willys B, López-Cervantes J. High-performance liquid chromatography with fluorescence detection for quantitation of tryptophan and tyrosine in a shrimp waste protein concentrate. Journal of Chromatography B, 2008, 863(1):88-93

\section{How to cite this article:}

Herpandi, Rosma A, Wan Nadiah WA, Febrianto NA, Huda N.. Optimization of enzymatic hydrolysis of skipjack tuna by-product using protamex ${ }^{\circledR}$ : a response surface approach. J. Fundam. Appl. Sci., 2017, 9(2S), 845-860. 